\title{
Estimating Prospects of Russian Foreign Trade under Crisis: Sanctions and Countersanctions
}

\author{
D.V. Manushin ${ }^{1 *}$ \\ *Corresponding author: predmet22@,mail.ru. \\ ${ }^{1}$ Kazan Innovative University named after V.G. Timiryasov, Kazan, Russia
}

\begin{abstract}
Based on econometric modeling, we proved the good relationship between foreign trade turnover and trade balance with the GDP of the Russian Federation. We identified the varying opinions of the Russian and foreign scholars on the impact of sanctions and countersanctions on the Russian economy. Based on the data on the absolute values of the trade turnover, export, import, and trade balance of Russia from 2010 to 2018, we revealed the positive dynamics of these indices, despite their negative values in 2014-2016. This allowed making a conclusion that the overall results of imposing sanctions and countersanctions for the Russian trade turnover and trade balance is rather positive than negative. This refutes the statements of western politicians, representatives of their subordinate international organizations, and some Russian and foreign scholars about the definitely negative role of sanctions and countersanctions. As a result, it is proposed to review the prospects of imposing additional countersanctions on western countries, which would allow developing the non-food sectors of the Russian economy.
\end{abstract}

Keywords: trade turnover, sanctions, export, import, balance.

\section{Introduction}

Today, the overall results of foreign trade are relatively poorly studied. The main attention in this sphere is paid to the export of energy carriers, which is studied in many macroeconomic works (for example, A.S. Ivanov and I.E. Matveev, 2018) [1]. At the same time, the importance of overall trade turnover (export and import) and its prospects is underestimated. To substantiate the importance of studying the Russian trade turnover, we research its relationship with the GDP of the Russian Federation. For that, we build a regression model based on quarterly absolute sums of the Russian trade turnover and GDP (bln rubles) from 1 January 2010 to 31 December 2018 (the total of 36 observations) using the data of Rosstat, Federal Customs Service and RateStats.com websites (to determine the dollar rate to ruble). As an explained variable, the model uses the summarized GDP RF, and the explanatory variable is the summarized foreign trade turnover of the Russian Federation (further - FTT RF):

$$
\mathrm{GDP} \text { RF }=3922+2.03 * \mathrm{FTT} \text { RF }+\mathrm{e}
$$

$$
\text { (3.13) (12.64) }
$$

In brackets below this and further formulas, $\mathrm{t}$-statistics are given. In this model the connection between the studied indices is very good. Its $\mathrm{R}^{2}$ is 0.82 ; t-statistics is 12.64 ; F-value is 0.000 (The acceptable value of probability according to null-hypothesis is 0.05 , the good value is 0.01 or less. These values show that one may reject the null-hypothesis saying that there is no relation between these indices and accept the alternative hypothesis that there is such a relationship. The acceptable value of tstatistics is more than 2 (modulo), and the good value is more than 4 (modulo)).. The positive sign in the model indicates the presence of direct connection between these indices. Thus, it follows from the model that the growth of foreign trade turnover of the Russian Federation increases its gross domestic product. All this confirms the importance of researching the Russian foreign trade under modern conditions, given that many scholars consider these conditions to be crisis because of the sanctions imposed on Russia.

In this regard, we set the goal to define the current state and development prospects of foreign trade of the Russian Federation. To that end, it is necessary to estimate the impact of sanctions and countersanctions on it. Estimation will be made both by expert opinions and the data of Russian statistics.

As a result, we plan to answer a number of questions. First, whether the Russian foreign trade is currently under explicit crisis or not. Second, what influence - positive or negative - the sanctions had on the Russian economy in general. To that end, the Russian foreign trade from 2010 to 2018 was studied, as during the period from the end of 2011 till the beginning of 2014 the oil prices were atypically high (mainly due to the civil war in Libya, which temporarily excluded this country from the list of largest oil exporters), and the period from the end of 2014 till the end of 2016 was the period of Russia's adaptation to the new conditions, which does not allow researching the mid-term and long-term prospects of Russia in the sphere of foreign trade.

The main objective of the research is to determine, which of the possible options would be the best: to try to transfer from sanctions to constructive dialogue, to maintain the current status quo, or to head for toughening the sanction policy. An auxiliary objective is to achieve understanding regarding the presence or absence of the necessity to implement anti-crisis measures in the Russian foreign trade. Achieving these objectives would allow the researchers to elaborate an optimal strategy of the Russian foreign trade and policy. 


\section{Methods}

To achieve the set goals, we used abstract-logical, economic-statistical, and economic-mathematical methods. The review of the Russian and foreign sources was carried out via search engines Scholar.google.ru, Yandex and Elibrary.ru by the key words: international trade, trade with Russia, sanctions and countersanctions. Modeling was carried out with the econometric software package QSR Eviews, based on the data presented at the websites of Rosstat, Federal Customs Service, and RateStats.com.

\section{Results}

\subsection{Literature review}

Today, the key factor influencing foreign trade is the political factor, first of all sanctions and countersanctions. During the one and a half years of imposing sanctions and countersanctions, many opinions have been expressed. They can be classified into three groups:

1. In January 2015, the US President B. Obama claimed that after the sanctions were introduced "the Russian economy is in tatters". The IMF report on the Russian economy states that at the initial stage sanctions and countersanctions may lead to the GDP decrease by $1-1.5 \%$, while in the middle-term the accumulated losses may reach $9 \%$ of the GDP [1]. The panic reaction to these words was the opinion that "sanctions are critical for the Russian economy. Under such conditions, the prospects of crisis management should be associated with as fast as possible normalization of cooperation with the foreign partners" [2, p. 35].

2. "The US and EU sanctions provide a unique opportunity to correct the skews in the Russian financial system with great advantage for it. If a country has a positive trade balance, it needs no foreign credits" [3, p. 21].

3. "The sanctions, worsening the situation in the Russian economy, are not the initial cause of its current state" [4, p. 77]. "For example, a much more sensible shock for the Russian economy is drop of oil prices" [1, p. 33]. The situation was aggravated by a significant increase of the key rate by the Russian Central Bank [3]. As a result, the conclusion is made that the main problem of the Russian economy is not sanctions but high taxes, poor industrial development, low purchasing power of the population, and insufficient financing of the Russian regions [5]. As time has shown, the second and third opinions were more grounded and objective.

Having studied the amounts of the Russian and global trade in the period from 2013 to 2017, S. V. Kazantsev (2019) found that the decline of trade turnover in 2014-2016 was observed not only in the Russian Federation but all over the world. The USA suffered the least from their sanctions. At that, they continue to expand and deepen anti-Russian sanctions, while the losses related to their implementation are born by other countries [6]. At that, many foreign scholars are certain that the negative impact of sanctions and countersanctions on the Russian foreign trade is still rather large, and only a small part of them argue for their lifting. For example, S. Krapohl and A. Vasileva-Dienes (2019) assert that "the economic recession in Russia since 2014, aggravated by the Western sanctions and low oil prices, makes Russia less attractive as a market for exporting from Central Asia" [7].

M. Bělín and J. Hanousek (2019) believe that the Russian sanctions, imposed on importing food from Europe and America, have led to about 8 times reduction of trade flow compared with the sanctions imposed by the EU and the USA in regard to exporting equipment. These results are probably not related to redirection of trade flows through unsanctioned countries. Hence, the difference in the sanctions efficiency can be explained by a broader range of sanctioned goods and a potentially stronger position of imposing sanctions on import compared to export [8].

I. Korhonen, H. Simola, and L. Solanko (2018) assert that sanctions had an obvious negative effect on the Russian economy, although the oil price decrease had a larger impact on the Russian GDP in 2014-2016. The Russian countersanctions hampered food exports from the EU, nut macroeconomic effects in the EU are very weak. At the same time, it is probable that if sanctions continue for a longer period, then the potential of Russia's long-term growth can be diminished [9].

M. Smeets (2018) revealed the reverse connection between the duration and efficiency of sanctions, i. e. the damage caused by them diminishes with time. It is rather unlikely that Russia would refuse its interests in the Ukrainian territory. The situation more and more looks like an accomplished fact. Analysis showed that maintaining the sanctions expecting that they would work long-term is unrealistic and is not proved by evidence. At some moment it will be necessary to make a decision regarding the duration and amount of the sanctions and ultimately their lifting [10].

P. Kurečić (2017) highlights the political reasons for the necessity of sanction policy of the West and marks that some NATO members almost completely depend on the Russian gas imports due to their geographical position, which impedes the possibility for them to follow the NATO and EU official policy regarding Russia. As a result, they attempt to maintain good relations with Russia, pursue their economic interests and ensure the best positions for increasing trade with Russia as soon as the EU lifts the sanctions. At that, oil and natural gas have been relatively cheap in the recent three years, which led to serious economic problems in Russia. That is why Russia cannot currently use gas supplies as a means of "gas wars". Some NATO/EU members from this region are not seriously interested in deterring Russia and protecting their state borders with troops and, most likely, would be willing to lift the sanctions. This does not mean that the NATO unity and resolution to act are threatened, especially as the actual military capabilities of the above- 
mentioned states are virtually negligible compared to those of Russia, which increases the homogeneity of these states and their dependence on NATO (the USA, first of all) in terms of security [11].

Review of the foreign authors' opinions shows that there is a common opinion on the crisis in the Russian economy as a result of sanctions imposition, reduction of prices for fuel-energy resources, and other difficulties. At the same time, many of these authors do not take into account the new course of the US foreign policy aimed at divergence from the WTO rules and unilateral promotion of US protectionist measures (these aspects are thoroughly commented by A. P. Portanskiy (2017) [12]). This course makes other countries consolidate. Besides, the above-mentioned authors, as a rule, do not estimate the mid- and long-term prospects of Russia's functioning under sanctions and countersanctions.

A. N. Lyakin and M. I. Rogov (2017) note that countersanctions have already provided achievement of the set goals. In a number of aspects, active investment is already going on (for example, vegetables grown under cover) and he market will hardly become open under any changes in geopolitics. For example, even recovery of relations with Turkey did not lead to lifting limitations for products into import substitution of which large investments were made [13].

Estimating the Russian countersanctions, E.L. Zolotareva (2018) emphasizes their negative impact on foreign economic links. At that, the European Union is still the largest trade partner of the Russian Federation. The share of the European Union countries in the Russian foreign trade turnover was $42.2 \%$ in 2017 , although it decreased a little. Recently, trade cooperation between Russia and APEC countries is activated, mainly countries of South-Eastern Asia: China, South Korea. Vietnam, and others. The unit weight of this group of countries is growing and in 2107 it was over $30 \%$. The share of Chine in the Russia's foreign trade reached 15\%. Russia exports to China meat, fruit and various ready foods. Russia imports from China vegetables, fruit, various kinds of meat [14]. When estimating this aspect, one should note that ecological situation is very bad in China; they apply a lot of fertilizers prohibited in Russia, which influences the quality of exported goods. As far as it is possible, Russia should reject importing food from China.

According to S.N. Larin (2019), it is too early to assert that sanction limitations against the Russian economy have reached their goals [15]. The review of works by the Russian researchers revealed that there is no unambiguous opinion about positive or negative influence of sanctions and countersanctions; the topic is rather disputable, which determines the need to study it in detail.

\subsection{Experimental research results}

To estimate the correlation of the studied opinions with the actual situation in the sphere of the Russian foreign trade, we research its changes in the period of 2010-2018 (see Fig. 1).

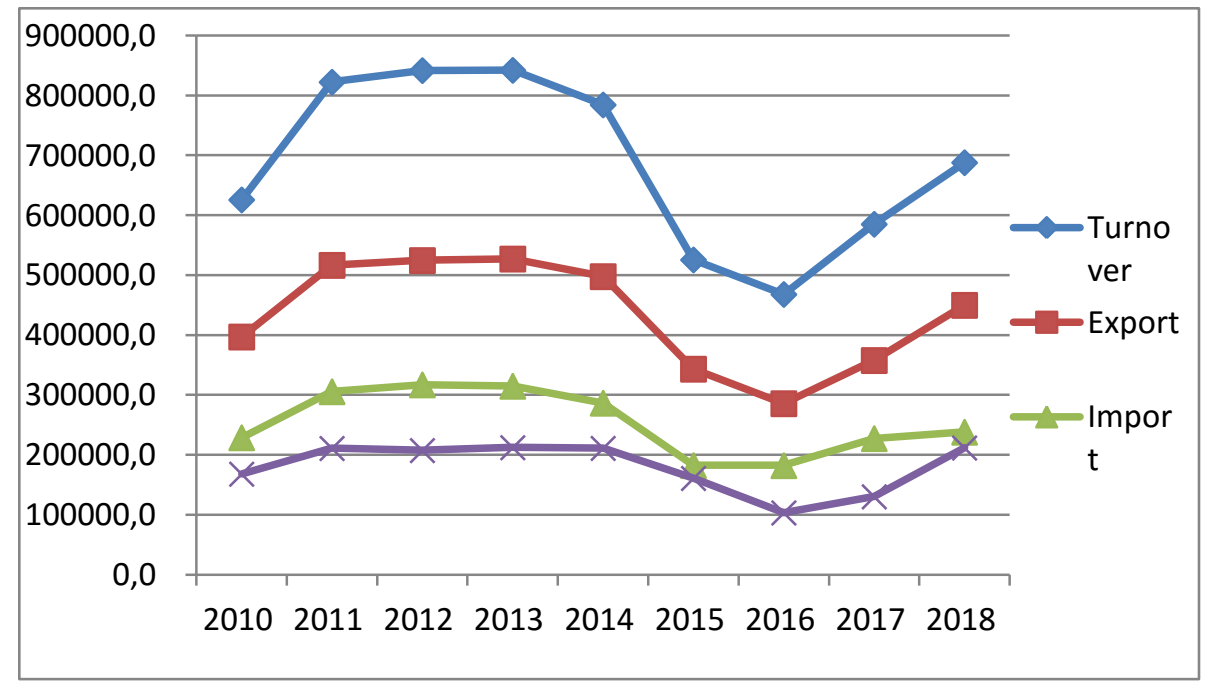

Fig. 1. Trade turnover, export, import, and trade balance of Russia from 2010 to 2018, mln US\$ (Source: Authors).

Analyzing Fig. 1, one may conclude that sanctions and countersanctions had significant influence on the Russian foreign trade in 2014-2018. At that, the overall result of imposing sanctions and countersanctions is rather positive than negative. For example, the Russian trade turnover in 2018 surpassed that in 2010 and it is expected that in 2019-2020 it will be comparable to the pre-crisis values of 2012-2013. At that, the trade balance in 2018 is already comparable to that in 2012-2013. In 2018, one may vividly see a significant reduction of import growth rate compared to export growth rate. Apparently, it is the result of successful implementation of the programs of import substitution, import exclusion, and entering new markets of import goods.

As the Russian trade balance demonstrates the best results after imposition of sanctions and countersanctions, it is necessary to estimate its impact of the GDP RF. For that, we build a regression model based on quarterly absolute sums of the Russian trade balance and GDP (bln rubles) from 1 January 2010 to 31 December 2018 (the total of 36 observations), using the data from the websites of Rosstat, Federal Customs Service, and RateStats.com (to determine the dollar rate to ruble). As the explained variable, the model uses the summarized GDP RF, and the explanatory variable is the summarized foreign trade balance of the Russian Federation (further - FTB RF): 
$\mathrm{GDP} \mathrm{RF}=10013.9+4.65 * \mathrm{FTB} \mathrm{RF}+\mathrm{e}$

(6.05) (5.89)

In this model the connection between the studied indices is good. Its $\mathrm{R}^{2}$ is 0.505 ; $\mathrm{t}$-statistics is 5.89 ; F-value is 0.0000. The positive sign in the model indicates the presence of direct connection between these indices. Thus, it follows from the model that the growth of foreign trade balance of the Russian Federation increases its gross domestic product. It is important to note that though the changes in trade balance explain just $50.5 \%$ of changes in GDP RF, but this is a good result, showing an apparent and rather significant connection between these indices.

\section{Conclusion}

The research proves the presence of firm and direct connection between the international trade turnover and balance of the Russian Federation and its GDP. It is shown that the overall mid-term result of sanctions and countersanctions for the Russian trade turnover and balance is rather positive than negative. This refutes the statements of western politicians and representatives of their subordinate international organizations, and some Russian and foreign scholars about the definitely negative role of sanctions and countersanctions. At that, one may expect that the revealed trend will be preserved and there will undoubtedly positive results in the Russian international trade. In this regard, Russia is recommended to make efforts to preserve the key sanctions and countersanctions, as they motivated the Russian government to activate international trade and achieve undoubted success under the crisis caused by Russophobic actions of the western countries. All this demonstrates the lack of evident crisis in the Russian international trade. As for the feasible termination of the agreement on gas transportation with Ukraine, Russia is ready for that. The gas pipelines "The Power of Siberia", "Nord Stream" and "TurkSteam" are already built and ready for operation.

Due to the revealed results and the success achieved in foreign trade, it is proposed that the Russian Federation continues its active policy in the sphere of import substitution, import exclusion, and entering new markets of export and import goods. Provided these activities are implemented, the prospects of the international trade will be advantageous for Russia. At that, it would be reasonable to explore the opportunity of imposing additional countersanctions onto the western countries, which would enable to further develop the non-food industries in Russia.

\section{References}

1. A.S. Ivanov, I.E, Matveev, International trade in fuel and energy products: Current state and prospects. Russian Foreign Trade Bulletin, 3, 46-56 (2018). [in Rus.].

2. E.T. Gurvich, I.V. Prilepskiy, The impact of financial sanctions on the Russian economy. Voprosy Ekonomiki, 1, 535 (2016). [in Rus.].

3. S.A. Afontsev, Crisis management under economic sanctions: Mission impossible? Voprosy Ekonomiki, 4, 20-36 (2015). [in Rus.].

4. S.Yu. Glazyev, Sanctions of the USA and the policy of Bank of Russia: Double blow to the national economy, Voprosy Ekonomiki, 9, 13-29 (2014). [in Rus.].

5. M.V. Klinova, E.A. Sidorova, Economic sanctions and EU-Russia economic relations. Voprosy Ekonomiki, 12, $67-$ 79 (2014). [in Rus.].

6. S.V. Kazantsev, Evaluation of the sanctions impact on sanctioning countries' trade with Russia. Finance: Theory and Practice, 23(3), 6-15 (2019).

7. S. Krapohl, A. Vasileva-Dienes, The region that isn't: China, Russia and the failure of regional integration in Central Asia. Asia Europe Journal (2019). DOI: 10.1007/s10308-019-00548-0.

8. M.Bělín, J.Hanousek, Which sanctions matter? Analysis of the EU/Russian sanctions of 2014. CEPR Discussion Paper No. DP13549 (2019). URL: https://econpapers.repec.org/paper/cprceprdp/13549.htm. Accessed: 09.09.2019.

9. I. Korhonen, H. Simola, L. Solanko, Sanctions and countersanctions - effects on economy, trade and finance. Focus on European Economic Integration, Oesterreichische Nationalbank (Austrian Central Bank), Q3-18, 68-76 (2018).

10. M. Smeets, Can economic sanctions be effective? Staff Working Paper, ERSD-2018-03 (2018). URL: https://www.wto.org/english/res_e/reser_e/ersd201803_e.pdf. Accessed: 09.09.2019.

11. P. Kurečić, The 'New Cold Warriors' and the 'Pragmatics': The differences in foreign policy attitudes towards Russia and the Eastern partnership states among the NATO member states from Central and South-Eastern Europe, Croatian International Relations Review, 23(80), 61-96 (2017).

12. A.P. Portanskiy, Trump presidency changes prospects of international trade. USA and Canada: Economy, Policy, Culture, 11(575), 83-96 (2017).

13. A.N. Lyakin, M.I. Rogov, Sanctions and counter-sanctions: Using political instruments to realize economic goals. National Interests: Priorities and Security, 13(8(353)), 1396-1414 (2017). [in Rus.].

14. E.L. Zolotareva, International food trade: Trends, problems, predictions. Bulletin of Kursk State Agricultural Academy, 4, 158-162 (2018). [in Rus.].

15. S.N. Larin, Sanction limitations of the West against Russia and the Russian contractions: Compensation of damages. Journal of Economy and Business: Theory and Practice, 4-2, 115-121 (2019). [in Rus.]. 